\title{
PENGEMBANGAN RUBRIK KETERAMPILAN PRAKTIK DAN SIKAP ILMIAH PADA PRAKTIKUM BIOKIMIA: KAJIAN VALIDITAS DAN RELIABILITAS
}

\section{DEVELOPING A PRACTICAL SKILLS RUBRIC AND SCIENTIFIC ATTITUDE TEST FOR LABORATORY ACTIVITY IN BIOCHEMISTRY COURSE: VALIDITY AND RELIABILITY STUDY}

\author{
Yunita Arian Sani Anwar*, Eka Junaidi, dan Syarifa Wahidah Al Idrus \\ Program Studi Pendidikan Kimia FKIP Universitas Mataram, Mataram, Indonesia \\ *Email: yunita@unram.ac.id
}

Diterima: 4 Januari 2021. Disetujui: 7 Januari 2021. Dipublikasikan: 20 Januari 2021

\begin{abstract}
Abstrak: Penelitian ini bertujuan untuk mengembangkan instrumen keterampilan praktik dan sikap ilmiah dalam kegiatan laboratorium mata pelajaran biokimia. Penilaian instrumen diawali dengan expert judgement menggunakan analisis indeks Aiken untuk validasi, dan Interclass Correlation Coefficients (ICC) untuk uji reliabilitas. Instrumen yang valid diujikan kepada 123 responden dan dianalisis menggunakan korelasi item-total korelasi dan Cronbach's alpha dengan menggunakan program software SPSS versi 21. Pada rubrik keterampilan praktis terdapat 18 indikator dan 44 pernyataan dalam angket sikap ilmiah yang dinyatakan valid oleh para ahli sebagai instrumen, dan memiliki reliabilitas sedang. Uji coba pada responden menunjukkan bahwa rubrik keterampilan praktik dan sikap ilmiah memiliki validitas dan reliabilitas yang baik untuk menilai kegiatan laboratorium pada mata kuliah biokimia. Instrumen ini diharapkan dapat memudahkan penilaian pada pembelajaran biokimia di laboratorium.
\end{abstract}

Kata Kunci: Keterampilan Praktik, Sikap Ilmiah, Validitas, Reliabilitas, Praktikum Biokimia

\begin{abstract}
This study aims to develop practical skill instruments and scientific attitude in the laboratory activities in biochemical subject. The assessment of the instrument was started with the expert judgment using Aiken index analysis for the validation and Interclass Correlation Coefficients (ICC) for the reliability test. The valid instrument was tested to the 123 respondents and was analyzed using correlated item-total correlation and Cronbach's alpha by using SPSS software version 21 program. There were 18 indicators in the practical skills rubric and 44 statements in the scientific attitude questionnaire were stated as valid instruments by the experts and they had a fair reliability. The pilot test on the respondents showed that the practical skill and scientific attitude rubric had good validity and reliability to assess the laboratory activities in the biochemical subject. These instruments were expected to be able to ease the assessment on the biochemical learning in the laboratory.
\end{abstract}

Keywords: Practical Skills, Scientific Attitude, Validity, Reliability, Biochemistry.

\section{PENDAHULUAN}

Sejak 2014, pendidikan tinggi di Indonesia menerapkan kurikulum baru yang disebut Kerangka Kualifikasi Nasional

Indonesia (KKNI). Peningkatan ini diharapkan dapat memenuhi pencapaian peran perguruan tinggi di Indonesia: jejaring dari komunitas lokal hingga global; berubah dari kohesi sosial menjadi partisipasi demokratis; dan berubah dari pertumbuhan ekonomi ke pembangunan manusia [1].

Penerapan KKNI pada perguruan tinggi di Indonesia diharapkan dapat menghasilkan pendidikan yang membentuk siswa yang memiliki kemampuan dalam keterampilan, pengetahuan, dan sikap. Lulusan harus memiliki tidak hanya keterampilan yang berkaitan dengan pengetahuan dan ilmu pengetahuan, tetapi juga memiliki sikap khas sebagai soft skill mereka. Oleh karena itu, pendidikan karakter menjadi bagian terpenting dalam proses pembelajaran di tingkat universitas.

Apa itu pendidikan karakter? Pala [2] menyatakan bahwa pendidikan karakter adalah sebagai gerakan nasional untuk menciptakan sekolah yang menjaga etika, orang-orang muda yang bertanggung jawab, memiliki kepedulian dan mengajarkan karakter yang baik melalui penekanan pada norma-norma universal yang dipahami semua orang. Hal ini terkait dengan apa yang dilihat, dilakukan, dan dilakukan oleh siswa [3]. Pendidikan karakter diharapkan mampu menciptakan individu yang berkualitas, berpikiran terbuka, dan berwawasan keberagaman sehingga membantu individu untuk hidup dan berkolaborasi sebagai satu keluarga, komunitas, dan bangsa [46]. Pada implementasi kurikulum KKNI karakter yang dibentuk dalam pendidikan adalah sikap [1] .

Biokimia merupakan salah satu mata kuliah wajib dalam program studi 
pendidikan kimia. Mahasiswa diharapkan mampu menampilkan karya yang mandiri, berkualitas, dan berwujud. Selain itu, mahasiswa diharapkan memiliki sikap ilmiah di bidang biokimia.

Di sisi lain, baik mahasiswa maupun dosen memiliki kendala dalam mata kuliah biokimia. Siswa mengalami kesulitan dalam memahami konsep sehingga terjadi penurunan minat dan aktivitas di kelas [7-9]. Selain itu, dosen kesulitan dalam memvisualisasikan konsep abstrak [10]. Kurikulum pembelajaran biokimia tidak terlepas dengan praktikum. Ada beberapa kendala yang biasa dijumpai dalam pekerjaan laboratorium di antaranya pekerjaan belum terintegrasi, ekspositori lebih dominan, dan belum ada instrumen untuk menilai keterampilan siswa [11].

Saat ini, instrumen yang valid untuk menilai pekerjaan dan sikap siswa terhadap praktikum biokimia belum dikembangkan. Di Indonesia, pekerjaan laboratorium dinilai hanya dengan observasi kemampuan mahasiswa dalam pengoperasian alat laboratorium. Keterampilan praktik dan sikap ilmiah belum termasuk dalam penilaian kegiatan belajar mahasiswa.

Pekerjaan laboratorium di universitas ini dilakukan tidak hanya untuk menjembatani teori dan fakta, tetapi juga untuk melatih keterampilan praktik mahasiswa [12]. Selain itu, pelaksanaan praktikum mampu meningkatkan rasa percaya diri dan melatih kemampuan argumentasi mahasiswa $[13,14]$.

Keterampilan praktik didefinisikan sebagai media bagi seseorang untuk beradaptasi terhadap kemampuannya [15]. Secara umum keterampilan dibagi menjadi tiga bagian yaitu psikomotorik, afektif, dan kognitif. Kumar [16] membagi keterampilan menjadi empat kategori, yaitu keterampilan praktik dan manipulatif, keterampilan observasi, keterampilan menggambar, serta keterampilan melaporkan dan menafsirkan. Dalam studi ini, keterampilan praktik didefinisikan sebagai kemampuan siswa untuk mengembangkan kemampuan intelektual dan psikomotorik melalui kegiatan laboratorium. Kategori keterampilan yang digunakan dimodifikasi dari Kumar [16] yang meliputi keterampilan prosedural, keterampilan manipulatif, keterampilan observasi, keterampilan menggambar, keterampilan menafsirkan, dan keterampilan melaporkan.

Sikap ilmiah adalah sikap yang diperlukan untuk dapat menerapkan proses ilmiah [17]. Selain itu, seseorang harus memiliki pengetahuan yang diperoleh dari proses yang dilakukan oleh ilmuwan. Sikap ini diperlukan untuk mengatasi masalah yang akan datang dengan pengetahuan yang terverifikasi [18]. Karakteristik dari pengetahuan ilmiah yang berpikiran terbuka, rasa ingin tahu, penilaian diverifikasi, kritis, percaya diri, siap mempertimbangan keputusan, jujur dalam mengumpulkan dan melaporkan data ilmiah penting dalam observasi, menerima kesimpulan akhir, dan mempercayai tulisan ahli yang berdasarkan pada data [19].

Sikap ilmiah dalam penelitian ini diartikan sebagai kesatuan proses dan keterampilan berpikir kritis yang ditunjukkan dalam tindakan dan kebiasaan secara sadar. Indikator yang disesuaikan dengan kurikulum KKNI adalah (1) rasa ingin tahu, (2) berpikiran terbuka, (3) objektivitas, (4) jujur dalam melaporkan hasil, (5) tanggung jawab, dan (6) saling menghargai [1].

Penelitian ini bertujuan untuk mengembangkan instrumen yang valid dan reliabel untuk menilai keterampilan praktik dan sikap ilmiah mahasiswa pada praktikum biokimia.

\section{METODE PENELITIAN \\ Desain Penelitian}

Pengembangan instrumen penilaian keterampilan praktik dan sikap ilmiah diawali dengan mempelajari literatur terkait pada kategori yang akan digunakan. Kategori ketrampilan praktIk adalah ketrampilan prosedural, ketrampilan manipulatif, ketrampilan observasi, ketrampilan menggambar, ketrampilan menafsirkan, dan ketrampilan melaporkan [16]. Kategori sikap ilmiah menurut kurikulum di Indonesia adalah rasa ingin tahu, berpikiran terbuka, objektivitas, jujur dalam melaporkan hasil, bertanggung jawab, dan saling menghargai [1]. Setiap kategori pada instrumen keterampilan praktis dan sikap ilmiah dikembangkan menjadi beberapa indikator. Setiap indikator memiliki kriteria penilaian untuk rubrik keterampilan praktik dan instrumen sikap ilmiah. Sebanyak 3 ahli melakukan penilaian terhadap instrumen dengan kategori penilaian sangat kurang (1), kurang (2), cukup (3), baik (4), dan sangat baik (5). Validitas dan reliabilitas hasil penilaian para ahli dikumpulkan dan ditabulasi. Validitas konstruk instrumen yang valid diuji untuk responden untuk mendapatkan instrumen yang valid dan dapat diandalkan. Desain penelitian disajikan pada Gambar 1.Penelitian ini menggunakan Rubrik Hoyo [10] dalam menganalisis laporan praktikum mahasiswa. Komponen laporan yang dinilai meliputi abstrak, sumber informasi, organisasi, relevansi, konten, dan presentasi. Masing-masing komponen dikembangkan kriteria penilaian dengan skala penilaian 1-4.

\section{Teknik Analisis Data}

Partisipan penelitian adalah para mahasiswa yang pernah mengambil mata kuliah biokimia di tiga perguruan tinggi negeri di Indonesia. Semua siswa mengikuti kegiatan pembelajaran baik di dalam kelas maupun di laboratorium. Ada empat topik yang dipelajari yaitu identifikasi karbohidrat, 
identifikasi protein, identifikasi enzim, dan identifikasi lemak. Variabel sampel didasarkan pada faktor demografi yang disajikan pada Tabel 1 .

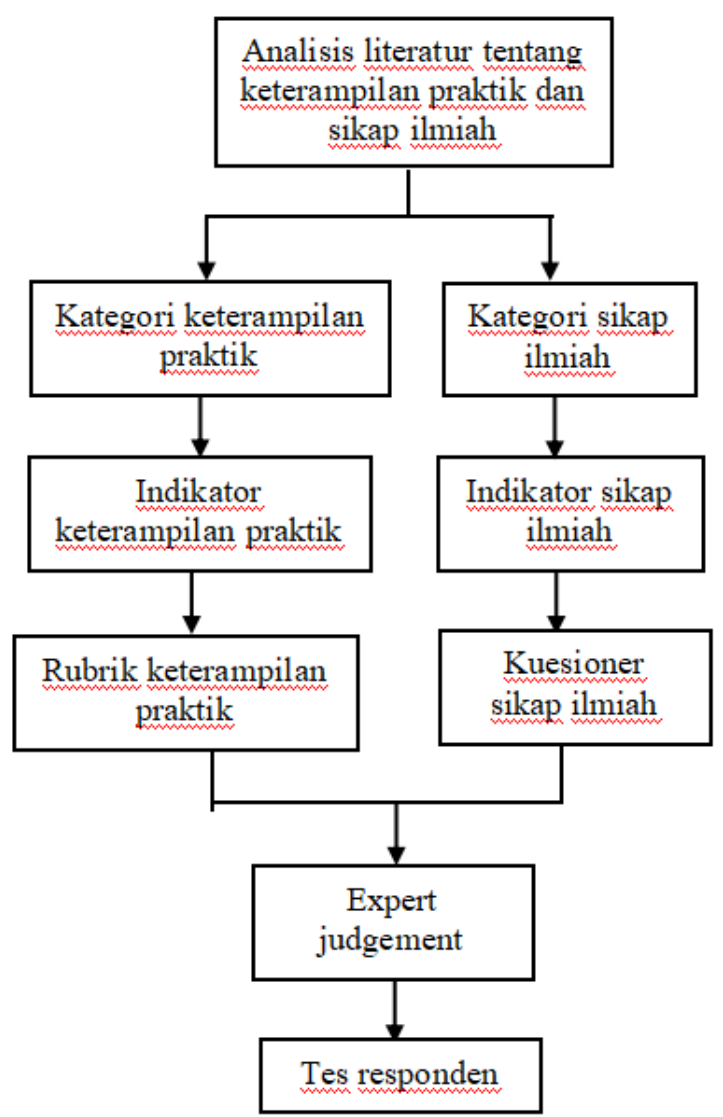

Gambar 1. Desain Penelitian

Tabel 1. Faktor Demografi Sampel

\begin{tabular}{lcc}
\hline \multirow{2}{*}{ Latar Belakang } & \multicolumn{2}{c}{ Sub total } \\
\cline { 2 - 3 } & $\mathrm{n}$ & $\%$ \\
\hline Jenis Kelamin & & \\
Laki-laki & 39 & 31.7 \\
Perempuan & 84 & 68.3 \\
\hline Universitas & & \\
Universitas I & 38 & 30.9 \\
Universitas II & 50 & 40.6 \\
Universitas III & 35 & 28.5 \\
\hline
\end{tabular}

\section{Instrumen Penelitian}

Keterampilan praktik mahasiswa diukur dengan menggunakan rubrik yang terdiri dari enam kategori di antaranya keterampilan prosedural, keterampilan manipulatif, keterampilan observasi, keterampilan menggambar, keterampilan menafsirkan, dan keterampilan presentasi. Setiap kategori dikembangkan menjadi beberapa indikator yang disajikan pada Tabel 3 .
Kuesioner sikap ilmiah disusun berdasarkan kategori: rasa ingin tahu, berpikiran terbuka, objektivitas, kejujuran dalam melaporkan hasil, bertanggung jawab, dan saling menghargai. Setiap kategori dikembangkan menjadi dua indikator (Tabel 4). Setiap indikator dikembangkan menjadi 2-4 pernyataan positif dan negatif dengan 5 jawaban: sangat setuju, setuju, ragu-ragu, tidak setuju, dan sangat tidak setuju. Teknik penilaian disajikan pada Tabel 2.

\section{Analisis Data}

Penilaian oleh ketiga ahli tersebut ditabulasi dan dihitung menggunakan indeks Aiken dari masing-masing indikator dan pernyataan dengan rumus [20]:

$$
V=\frac{\sum s}{n(c-1)}
$$

dimana $\mathrm{V}$ adalah kesepakatan para ahli; $s$ adalah skor yang diberikan ahli dikurangi dengan skor terendah dalam kategori penilaian; $n$ adalah jumlah ahli; dan $c$ adalah total kategori penilaian yang dipilih para ahli. Berdasarkan hasil perhitungan indeks $V$, suatu pernyataan atau indikator dapat dikategorikan berdasarkan indeksnya. Jika indeks kurang dari 0,4 validitas dinyatakan rendah; 0.4-0.8 validitasnya sedang; dan jika lebih dari 0.8 validitas dianggap tinggi [21]. Penelitian ini melibatkan lebih dari dua orang ahli, maka pengukuran reliabilitas menggunakan Interclass Correlation Coefficients (ICC) pada program SPSS 21[22].

Instrumen yang valid berdasarkan kesepakatan ahli diujikan kepada 123 responden. Uji validitas dilakukan dengan membandingkan korelasi item-total korelasi (r hitung) menggunakan $\mathrm{r}$ tabel. Jika $\mathrm{r}$ hitung lebih dari $r$ tabel dan skornya positif maka pernyataan atau indikator dinyatakan valid. Reliabilitas diuji dengan menggunakan reliabilitas konsistensi internal (Cronbach's alpha) menggunakan program SPSS 21[23].

Tabel 2. Skor Penilaian untuk pernyataan Positif dan Negatif

\begin{tabular}{lcc}
\hline & $\begin{array}{c}\text { Pernyataan } \\
\text { Positif }\end{array}$ & $\begin{array}{c}\text { Pernyataan } \\
\text { Negatif }\end{array}$ \\
\hline Sangat setuju & 5 & 1 \\
Setuju & 4 & 2 \\
Netral & 3 & 3 \\
Tidak setuju & 2 & 4 \\
Sangat tidak setuju & 1 & 5 \\
\hline
\end{tabular}


Tabel 3. Indikator Rubrik Keterampilan Praktik

\begin{tabular}{|c|c|c|}
\hline No & $\begin{array}{c}\text { Kategori Keterampilan } \\
\text { Praktik }\end{array}$ & Indikator \\
\hline 1. & Keterampilan prosedural & $\begin{array}{l}\text { Mampu menguraikan tujuan pelaksanaan praktikum biokimia dengan } \\
\text { tepat } \\
\text { Mampu menentukan alat yang dibutuhkan untuk praktikum biokimia } \\
\text { dengan tepat. } \\
\text { Mampu menentukan bahan yang dibutuhkan untuk praktikum biokimia } \\
\text { dengan tepat. } \\
\text { Mampu melaksanakan prosedur pelaksanaan praktikum biokimia } \\
\text { dengan baik }\end{array}$ \\
\hline 2. & Keterampilan manipulatif & $\begin{array}{l}\text { Mampu mengembangkan prosedur praktikum biokimia dengan baik. } \\
\text { Mampu memodifikasi prosedur praktikum biokimia dengan baik. } \\
\text { Mampu mengembangkan prosedur analisis data praktikum biokimia } \\
\text { dengan baik. }\end{array}$ \\
\hline 3. & Keterampilan observasi & $\begin{array}{l}\text { Mampu menemukan sejumlah hasil pengukuran pada praktikum } \\
\text { biokimia dengan baik. } \\
\text { Mampu melihat perubahan reaksi yang terjadi saat praktikum biokimia } \\
\text { dengan baik. } \\
\text { Mampu mengamati dengan baik. }\end{array}$ \\
\hline 4. & Keterampilan menggambar & $\begin{array}{l}\text { Mampu membuat tabel observasi praktikum biokimia } \\
\text { Mampu mendeskripsikan grafik dari data yang diperoleh pada } \\
\text { praktikum biokimia }\end{array}$ \\
\hline 5. & Keterampilan menafsirkan & $\begin{array}{l}\text { Mampu merekam data observasi saat praktikum biokimia } \\
\text { Mampu menginterpretasikan data yang diamati } \\
\text { Mampu membuat kesimpulan dari praktikum biokimia }\end{array}$ \\
\hline 6. & Keterampilan Presentasi & $\begin{array}{l}\text { Mampu berkomunikasi pada saat presentasi hasil praktikum biokimia } \\
\text { Mampu bekerja sama dengan tim saat presentasi hasil praktikum } \\
\text { biokimia } \\
\text { Mampu mengumpulkan informasi saat memberi pembahasan. }\end{array}$ \\
\hline
\end{tabular}

Tabel 4. Kategori dan Indikator Sikap Ilmiah

\begin{tabular}{cllc}
\hline No & \multicolumn{1}{c}{ Sikap Ilmiah } & \multicolumn{1}{c}{ Indikator } & $\begin{array}{c}\text { Nomor } \\
\text { Pernyataan }\end{array}$ \\
\hline 1. & Rasa Ingin Tahu & Memiliki minat ilmiah di bidang biokimia & $1,12,23,37$ \\
& & Memiliki minat pada informasi yang berkaitan dengan biokimia & $2,13,24,38$ \\
2. & Berpikiran terbuka & Memiliki minat untuk mengeksplorasi informasi lebih lanjut & $3,14,25,26$ \\
& & Menerima pendapat orang lain & $4,15,27,39$ \\
3. & Objektivitas & Menjadi apa adanya & $5,16,28,44$ \\
& & Mampu membedakan fakta dan opini & $6,17,29,40$ \\
4. & Jujur dalam & Bertindak/berbicara sesuai dengan kenyataan & $7,18,30,41$ \\
& melaporkan hasil & Tidak menambah atau mengurangi apapun & $8,19,31,42$ \\
5. & Bertanggung jawab & Menyelesaikan tugas sesuai waktu yang disepakati & 9,32 \\
& & Menyelesaikan tugas sesuai instruksi dosen & 20,33 \\
6. Saling menghargai & Menghargai teman dalam kelompok kerja & $10,21,34$, \\
& & & 43 \\
& & & $11,22,35$, \\
\end{tabular}

\section{HASIL DAN PEMBAHASAN}

Hasil validitas isi oleh para ahli menunjukkan bahwa indikator pada masing-masing kategori keterampilan praktik adalah valid. Skor indeks Aiken berkisar antara 0,58-0,83 dengan kategori sedang sampai dengan validitas tinggi. Secara keseluruhan rubrik keterampilan praktik dalam indeks Aiken memiliki skor 0,73 dengan kategori validitas sedang. Hasil uji validitas rubrik keterampilan praktik disajikan pada Tabel 5. 
Pengujian reliabilitas berdasarkan kesepakatan para ahli menunjukkan skor Interclass Correlation Coefficients (ICC) sebesar 0,511 dengan kategori reliabilitas sedang. Kesimpulannya, menurut para ahli, rubrik keterampilan praktis yang dikembangkan valid dan reliabel.

Hasil uji responden menunjukkan bahwa semua korelasi item-total skor korelasi pada masing-masing indikator lebih dari $\mathrm{r}$ tabel $(0,177)$. Setiap indikator divalidasi sebagai tolok ukur ketrampilan praktik pada kegiatan praktikum biokimia (Tabel 6). Hasil perhitungan reliabilitas konsistensi internal menunjukkan nilai Cronbach alpha sebesar 0,746. Menurut Nunally \& Bernstein [24], suatu instrumen valid jika skor Cronbach alpha lebih dari 0,70.

Tabel 5. Validitas Isi Rubrik Keterampilan Praktik

\begin{tabular}{|c|c|c|c|c|}
\hline No & Kategori & $\begin{array}{c}\text { Jumlah } \\
\text { Indikator }\end{array}$ & $\begin{array}{l}\text { Indeks } \\
\text { Aiken }\end{array}$ & $\begin{array}{l}\text { Kategori } \\
\text { Validitas }\end{array}$ \\
\hline \multirow[t]{4}{*}{1.} & Keterampilan prosedural & 1 & 0.83 & Tinggi \\
\hline & & 2 & 0.83 & Tinggi \\
\hline & & 3 & 0.83 & Tinggi \\
\hline & & 4 & 0.83 & Tinggi \\
\hline \multirow[t]{3}{*}{2.} & Keterampilan manipulatif & 1 & 0.75 & Medium \\
\hline & & 2 & 0,58 & Medium \\
\hline & & 3 & 0,58 & Medium \\
\hline \multirow[t]{3}{*}{3.} & Keterampilan observasi & 1 & 0.75 & Medium \\
\hline & & 2 & 0.75 & Medium \\
\hline & & 3 & 0.75 & Medium \\
\hline \multirow[t]{2}{*}{4.} & Keterampilan menggambar & 1 & 0.75 & Medium \\
\hline & & 2 & 0.75 & Medium \\
\hline \multirow[t]{3}{*}{5.} & Keterampilan menafsirkan & 1 & 0,58 & Medium \\
\hline & & 2 & 0.75 & Medium \\
\hline & & 3 & 0.75 & Medium \\
\hline \multirow[t]{3}{*}{6.} & Keterampilan Presentasi & 1 & 0.75 & Medium \\
\hline & & 2 & 0.75 & Medium \\
\hline & & 3 & 0.75 & Medium \\
\hline
\end{tabular}

Tabel 6. Validitas Konstruk Rubrik Keterampilan Praktik

\begin{tabular}{|c|c|c|c|c|}
\hline No. & Kategori Keterampilan Praktis & $\begin{array}{c}\text { Jumlah } \\
\text { Indikator }\end{array}$ & $\mathrm{r}$ & Kategori \\
\hline \multirow[t]{4}{*}{1.} & Keterampilan prosedural & 1 & 0.274 & Valid \\
\hline & & 2 & 0.248 & Valid \\
\hline & & 3 & 0.219 & Valid \\
\hline & & 4 & 0.204 & Valid \\
\hline \multirow[t]{3}{*}{2.} & Keterampilan manipulatif & 1 & 0,500 & Valid \\
\hline & & 2 & 0.426 & Valid \\
\hline & & 3 & 0,314 & Valid \\
\hline \multirow[t]{3}{*}{3.} & keterampilan observasi & 1 & 0,277 & Valid \\
\hline & & 2 & 0.246 & Valid \\
\hline & & 3 & 0.301 & Valid \\
\hline \multirow[t]{2}{*}{4.} & keterampilan menggambar & 1 & 0.256 & Valid \\
\hline & & 2 & 0.229 & Valid \\
\hline \multirow[t]{3}{*}{5.} & keterampilan menafsirkan & 1 & 0.216 & Valid \\
\hline & & 2 & 0.429 & Valid \\
\hline & & 3 & 0,320 & Valid \\
\hline \multirow[t]{3}{*}{6.} & Keterampilan melaporkan hasil & 1 & 0.358 & Valid \\
\hline & & 2 & 0.407 & Valid \\
\hline & & 3 & 0,367 & Valid \\
\hline
\end{tabular}

Saat ini, sangat sedikit penelitian tentang pengembangan instrumen penilaian keterampilan praktik pada aktivitas laboratorium mata kuliah biokimia. Rubrik penilaian hanya memuat aspek psikomotorik dan 
belum terintegrasi dengan kognitif dan afektif. Ruang lingkup ketrampilan praktek meliputi ketrampilan intelektual, psikomotorik, dan afektif [25]. Hal ini penting untuk tidak hanya siswa tetapi juga untuk dosen [26,27]. Terdapat 2 cara untuk menilai keterampilan praktik, yaitu menggunakan check list untuk menilai keterampilan manipulatif, keterampilan dalam mengatasi dan mengelola prosedur percobaan, dan pengamatan langsung terhadap pekerjaan siswa di laboratorium [28].

Penelitian ini mengembangkan keterampilan praktik tentang kegiatan laboratorium yang mencakup aspek psikomotorik, kognitif, dan afektif. Hasil penelitian menunjukkan bahwa semua indikator valid dan reliabel dengan nilai alpha Cronbach sebesar 0,746. Berbeda dengan penelitian Anthonia [29] yang mengembangkan penilaian keterampilan praktik kimia dengan skor alpha Cronbach sebesar 0,5312-0,9552. Selain itu, penelitian Chijioke \& Okeke Benchuks [30] mengembangkan instrumen dengan skor alpha Cronbach sebesar 0,95. Namun, skor alpha Cronbach dalam penelitian ini serupa dengan mereka yang mengembangkan instrumen keterampilan praktik dengan skor reliabilitas 0,75 dan 0,78 [31,32].

Terdapat 44 pernyataan sikap ilmiah dalam kegiatan laboratorium pada angket perkuliahan biokimia. Hasil validasi ahli menunjukkan bahwa semua pernyataan dalam angket sikap ilmiah valid dengan skor indeks Aiken sebesar 0,42-1 (Tabel 7). Pengujian reliabilitas menunjukkan skor ICC sebesar 0,64 dengan kategori reliabilitas adalah sedang.

Uji coba terhadap 123 responden menunjukkan bahwa terdapat 28 pernyataan yang valid dengan korelasi item-total nilai korelasi antara 0,210-0,654 (Tabel 8). Skor Cronbach alpha kuesioner sebesar 0,814. Hal tersebut menunjukkan bahwa angket memiliki reliabilitas yang baik. Penelitian Shah \& Mahmood [33] menunjukkan bahwa terdapat 54 item pernyataan kuesioner sikap ilmiah yang memiliki alpha Cronbach dengan skor 0,86. Penelitian Safdar \& Shah [34] menghasilkan 24 pernyataan pada instrumen dengan nilai reliabilitas KR-21 sebesar 0,88. Moore \& Foy [35] menghitung alpha cronbach sebagai 0,781.

Tabel 7. Validitas Isi Kuesioner Sikap Ilmiah

\begin{tabular}{cccccc}
\hline No & Indeks & Kategori & No & Indeks & Kategori \\
\hline 1 & 1.00 & Tinggi & 23 & 1.00 & Tinggi \\
2 & 1.00 & Tinggi & 24 & 1.00 & Tinggi \\
3 & 0.42 & Medium & 25 & 0.92 & Tinggi \\
4 & 0.83 & Tinggi & 26 & 0.92 & Tinggi \\
5 & 1.00 & Tinggi & 27 & 0.92 & Tinggi \\
6 & 0.92 & Tinggi & 28 & 1.00 & Tinggi \\
7 & 0.92 & Tinggi & 29 & 1.00 & Tinggi \\
8 & 0.42 & Medium & 30 & 0.42 & Medium \\
9 & 0.92 & Tinggi & 31 & 1.00 & Tinggi \\
10 & 0.92 & Tinggi & 32 & 0.92 & Tinggi \\
11 & 0.92 & Tinggi & 33 & 1.00 & Tinggi \\
12 & 0.83 & Tinggi & 34 & 0.83 & Tinggi \\
13 & 0.92 & Tinggi & 35 & 1.00 & Tinggi \\
14 & 0.92 & Tinggi & 36 & 0.92 & Tinggi \\
15 & 1.00 & Tinggi & 37 & 0.92 & Tinggi \\
16 & 1.00 & Tinggi & 38 & 1.00 & Tinggi \\
17 & 0.42 & Medium & 39 & 0.92 & Tinggi \\
18 & 0.92 & Tinggi & 40 & 0.92 & Tinggi \\
19 & 1.00 & Tinggi & 41 & 1.00 & Tinggi \\
20 & 1.00 & Tinggi & 42 & 0.92 & Tinggi \\
21 & 0.83 & Tinggi & 43 & 0.92 & Tinggi \\
22 & 0.92 & Tinggi & 44 & 0.42 & Medium \\
\hline
\end{tabular}

\section{KESIMPULAN}

Terdapat 18 indikator pada rubrik penilaian keterampilan praktikum kegiatan laboratorium mata pelajaran biokimia yang divalidasi oleh para ahli dengan indeks A iken antara 0,58 (validitas sedang) sampai dengan 0,83 (validitas tinggi). Skor ICC adalah 0,511 yang menunjukkan bahwa instrumen tersebut cukup handal. Hasil uji coba terhadap 123 responden menunjukkan nilai korelasi item-total korelasi seluruh indikator lebih dari $r$ tabel sehingga instrumen valid dengan nilai alpha cronbach 0,746. The kuesioner pada sikap ilmiah dalam kegiatan laboratorium pada subjek biokimia dikembangkan 44 pernyataan dan itu divalidasi oleh mantan perts dengan skor ICC 0,64. Dari hasil uji responden didapatkan 28 pernyataan yang valid dengan nilai Cronbach's alpha 0.814 . 


\section{DAFTAR PUSTAKA}

[1] Direktorat Jenderal Pendidikan Tinggi. (2014). Higher Education Curriculum. Kementerian Pendidikan dan Kebudayaan: Jakarta.

[2] Pala A. (2011). The need for character education. International Journal of Social Sciences and Humanity Studies, 3(2), 1-23.

[3] Davis M. What's wrong with character education? (2003). American Journal of Education, 110, 32-37.

[4] Hoge J. (2002). Character education, citizenship education, and the social studies. Social Studies, 93(3), 103-108.

[5] Almerico G.M. (2014). Building character through literacy with children's literature. Research in Higher Education Journal, 26, 113.

[6] Kamaruddin S.A. (2012). Character education and students social behavior. Journal of Education and Learning, 6(4), 223-230.

[7] Varghese J., Faith M., \& Jacob, M. (2012). Impact of E-Resources on Learning in Biochemistry: First-Year Medical Students Perceptions. BMC Medical Education, 12(21), 1-9.

[8] Anwar, Y.A.S., Junaidi, E., \& Al Idrus S.W. (2013). Analisis Kesulitan Belajar Biokimia Mahasiswa dalam Upaya Pengembangan Perangkat Pembelajaran Berbasis Daur Belajar Johnston. PAEDAGORIA Jurnal Kajian Penelitian dan Pengembangan Kependidikan, 8(2), $71-74$.

[9] Broman K., Ekborg, M., \& Johnels. (2011). Chemistry in crisis? Perspectives on teaching and learning chemistry in Swedish upper secondary schools. Nordina, 7(1), 43-53.

[10] Thomas, G.P., \& Anderson, D. (2014). Changing the Metacognitive Orientation of a Classroom Environment to Enhance Students' Metacognition Regarding Chemistry Learning. Learning Environment Research, 17, 139-155.

[11] Anwar, Y.A.S., Senam., Laksono, E.W. (2016). Development of Mini Laboratory Model for Biochemistry Learning. Not Publication.

[12] Reid, N., \& Shah, I. (2007). The Role Laboratory Work ini University Chemistry. Chemistry Education Research and Practice, 8(2), 172-185.

[13] Pickering, M. (1987). What goes on in students' heads in laboratory? Journal of Chemical Education, 64, 521-523.

[14] Hofstein, A, Kipnis, M, \& Kind, P. (2008). Learning in and from Science Laboratories: Enhancing Students Meta-Cognition and Argumentation Skills. Science Education Issues and Development, 1, 59-94.
[15] Adeyemo, S.A. (2010). The need for skill development/acquisition in science technology and mathematics education (STEM) in Nigeria. Journal of Science and Technology Education Research, 1(1), 1-9.

[16] Kumar A. (2010). Assessment of practical skill in science. New Delhi: Central Board of Secondary Education.

[17] Opong I.K. (1981). Science Education in Primary Schools: Toe Product of Science or The Way to Science. Journal Science Teachers Association of Nigeria,19(2), 9-17.

[18] Jancirani, R., Dhevakrishnan, R., \& Devi, S. (2012). A Study on Scientific Attitude of Adolescence Students in Namakkal District. Int Edu E-Journal, 1(4), 2-8.

[19] Kaur G. (2013). Scientific Attitude In Relation To Critical Thinking Among Teachers. Educationia Confab, 2(8), 24-29.

[20] Aiken, L.R. (1985). Three Coefficients for Analyzing the Reliability and Validity of Ratings. Educational and Psychological Measurement, 45, 131-142.

[21] Retnawati, H. (2016). Analisis Kuantitatif Instrumen Penelitian: Panduan Peneliti, Mahasiswa, dan Psikometrian. Yogyakarta: Parama Publishing.

[22] Widhiarso, W. (2005). Mengestimasi Reliabilitas. Yogyakarta: Fakultas Psikologi UGM.

[23] Ghozali, I. (2013). Aplikasi Analisis Multivariate dengan Program IBM SPSS 21: Update PLS Regresi. Semarang: Universitas Diponegoro.

[24] Nunnally, J., \& Bernstein, I.H. (1994). Psychometric Theory. New York: McGraw Hill.

[25] Sheeba, M.N. (2013). An anatomy of science process skills in the light of the challenges to realize science instruction leading to global excellence in education. Educationia Confab, 2(4), 108-123.

[26] Rayner, G., Familari, M., \& Blanksby, T. (2014). Assessing first year biology student practical skill: Benchmarking across the landscape. Refereed paper, 1-10.

[27] Chabalengula, V.M., Mumba, F., \& Mbewe, S. (2012). How pre-service teachers: Understand and perform science process skills. Eurasia Journal of Mathematics, Science \& Technology Education, 8(3), 167176.

[28] Hofstein, A. (2004). The laboratory in chemistry education: Thirty years of experience with developments, implementation, and research. Chemistry Education: Research and Practice, 5(3), 247264. 
[29] Anthonia, N.U. (2014). Factorial validation of an instrument for the assessment of practical chemistry skills acquisition. Journal of Education and Practice, 5(8), 175-185.

[30] P. Chijioke O, Okeke Benchuks. (2012). Development and validation of instrument for assessing practical skills in fault diagnoses and repairs of radio and television systems in Nigerian Techincal College. Am.J.Sci.Ind.Res., 3(3), 181-190.

[31] Kaletapwa, G.F., Kesiki, W.B., \& Amuche, C.I. (2014). Development and standardization of an instrument for assessing practicals among students in colleges of agriculture in Nigeria. International Journal of Education and Research, 2(6), 399-414.
[32] Sakiyo, J. (2009). Development and standardization of biology achievement test for SSS student in Adamawa state. Journal of Technology and Development, 11, 78-83.

[33] Shah, Z.A., \& Mahmood, N. (2011). Developing a scale to measure attitude towards science learning among school students. Bulletin of Education and Research, 33(1), 71-81.

[34] Safdar, M, \& Shah, I. (2014). The application of meaningful learning model of David Ausubel in teaching physics. Asian Journal of Education and E-Learning, 2(1), 35-42.

[35] Moore, R.W., \& Foy, R.L.H. (1997). The scientific attitude inventory: a revision (SAI II). Journal of Research in Science Teaching, 34(4), 327-336. 